\title{
Letter to the Editor: Early and midterm results of extended septal myectomy: Indian experience
}

\author{
Akhil Raj Anumolu ${ }^{1}$, Anumolu aakash ${ }^{2}$, and Satesh Kumar ${ }^{3}$ \\ ${ }^{1}$ Andhra Medical College \\ ${ }^{2}$ Bukovinskij Derzhavnij Medichnij Universitet \\ ${ }^{3}$ Shaheed Mohtarma Benazir Bhutto Medical College
}

February 18, 2022

\section{Hosted file}

akul.docx available at https://authorea.com/users/461222/articles/556972-letter-to-theeditor-early-and-midterm-results-of-extended-septal-myectomy-indian-experience 